\title{
"Corporate governance and quality of financial statements: a study of listed Nigerian banks"
}

\begin{tabular}{|c|c|}
\hline & Uwalomwa Uwuigbe iD https://orcid.org/0000-0001-8769-3492 \\
\hline & R http://www.researcherid.com/rid/G-2903-2018 \\
\hline & Eluyela Damilola Felix (D https://orcid.org/0000-0002-3080-6385 \\
\hline & Olubukola Ranti Uwuigbe iD https://orcid.org/0000-0002-6566-1083 \\
\hline AUTHORS & R http://www.researcherid.com/rid/G-2929-2018 \\
\hline & Obarakpo Teddy iD https://orcid.org/0000-0001-9579-4373 \\
\hline & R http://www.researcherid.com/rid/G-3098-2018 \\
\hline & $\begin{array}{l}\text { Falola Irene } \\
\text { R http://www.researcherid.com/rid/G-3100-2018 }\end{array}$ \\
\hline ARTICLE INFO & $\begin{array}{l}\text { Uwalomwa Uwuigbe, Eluyela Damilola Felix, Olubukola Ranti Uwuigbe, } \\
\text { Obarakpo Teddy and Falola Irene (2018). Corporate governance and quality of } \\
\text { financial statements: a study of listed Nigerian banks. Banks and Bank Systems, } \\
\text { 13(3), 12-23. doi:10.21511/bbs.13(3).2018.02 }\end{array}$ \\
\hline DOI & http://dx.doi.org/10.21511/bbs.13(3).2018.02 \\
\hline RELEASED ON & Thursday, 19 July 2018 \\
\hline RECEIVED ON & Monday, 12 March 2018 \\
\hline ACCEPTED ON & Tuesday, 12 June 2018 \\
\hline & $((\mathrm{cc}) \mathrm{EY}$ \\
\hline LICENSE & $\begin{array}{l}\text { This work is licensed under a Creative Commons Attribution } 4.0 \text { International } \\
\text { License }\end{array}$ \\
\hline JOURNAL & "Banks and Bank Systems" \\
\hline ISSN PRINT & $1816-7403$ \\
\hline ISSN ONLINE & $1991-7074$ \\
\hline PUBLISHER & LLC "Consulting Publishing Company "Business Perspectives" \\
\hline FOUNDER & LLC "Consulting Publishing Company "Business Perspectives" \\
\hline & 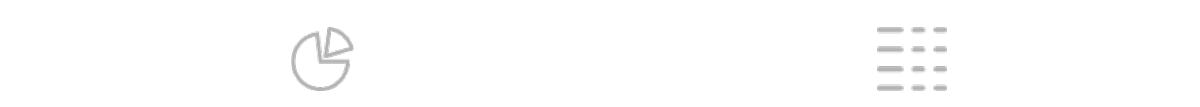 \\
\hline NUMBER OF REFERENCES & NUMBER OF FIGURES \\
\hline 64 & 0 \\
\hline
\end{tabular}

(c) The author(s) 2022. This publication is an open access article. 


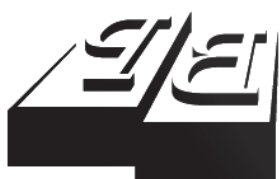

BUSINESS PERSPECTIVES

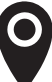

LLC "CPC "Business Perspectives" Hryhorii Skovoroda lane, 10, Sumy, 40022, Ukraine

www.businessperspectives.org

Received on: $12^{\text {th }}$ of March, 2018 Accepted on: $12^{\text {th }}$ of June, 2018

(c) Uwalomwa Uwuigbe, Eluyela Damilola Felix, Olubukola Ranti Uwuigbe, Obarakpo Teddy, Falola Irene, 2018

Uwalomwa Uwuigbe, Professor, Ph.D., Department of Accounting, Covenant University, Nigeria.

Eluyela Damilola Felix, Lecturer, Department of Accounting, Landmark University, Nigeria.

Olubukola Ranti Uwuigbe, Professor, Ph.D., Department of Accounting, Covenant University, Nigeria.

Obarakpo Teddy, M.Sc. Student, Department of Accounting, Covenant University, Nigeria.

Falola Irene, M.Sc. Student, Department of Accounting, Covenant University, Nigeria.

\section{(c) (i)}

This is an Open Access article, distributed under the terms of the Creative Commons Attribution 4.0 International license, which permits unrestricted re-use, distribution, and reproduction in any medium provided the original work is properly cited.
Uwalomwa Uwuigbe (Nigeria), Eluyela Damilola Felix (Nigeria),

Olubukola Ranti Uwuigbe (Nigeria), Obarakpo Teddy (Nigeria), Falola Irene (Nigeria)

\section{CORPORATE GOVERNANCE}

\section{AND QUALITY OF FINANCIAL STATEMENTS: A STUDY OF LISTED NIGERIAN BANKS}

\begin{abstract}
This study investigated the influence of Corporate governance on the timeliness of financial reports of listed banks in Nigeria. In order to provide answers to the research questions raised in this study, data were generated from the annual report of the listed banks on the Nigerian Stock Exchange considering the period 20082015. The study used Board size, Board Independence and Foreign Executives on the board as proxies for corporate governance. The data were analyzed using descriptive statistics, correlation matrix and panel data regression analysis. It was observed that board size had a non-significant negative relationship with the timeliness of financial reports. Also, the study observed that board independence also had a non-significant negative relationship with the timeliness of financial reports. Finally, it was observed that foreign executives on the board had a significant positive relationship with the timeliness of financial reports. The study thus recommends that the existing legal framework in Nigeria should be developed that clearly specifies the rights and obligations of a bank, its management and, of course, other stakeholders.
\end{abstract}

Keywords

JEL Classification M14, M41, M42
Financial reporting is no longer perceived or seen as a mere recording of transactions or an ordinary bookkeeping activity. It is now seen as a crucial tool in managing a company under good corporate governance principles (Uwuigbe et al., 2017). Financial reports according to Nassar, Uwuigbe, Uwuigbe, and Abuwa (2014), can be described as a systematic description of the financial performance and position of any entity; it actually provides information about the entity to a comprehensive range of users in order to make quality economic and financial decisions. According to IAS 1, "Financial reports present the performance of management as stewards of resources trusted to them". This concept has received significant interest from present and potential investors as well as other major stakeholders (Okereke, 2008). The main objectives of preparing financial statements are to enhance the quality of the decisions made by the users, however, users can only make quality decisions with the availability of quality financial information (Uwuigbe et al., 2016). According to Sloan (2001), the quality of financial information is still a key cause of worry for all current and potential investors. Consequently, for financial information to be of quality, financial reports should get to the users in a timely 
manner to enhance the effective use of such information (Alexander \& Britton, 2000). In the same vein, Lewis and Pendril, (1996) and Mainoma, (2002) opined that in order to actualize the objectives of the preparation of financial statements, financial information must be made available to the users in a timely manner to serve as an effective aid to the quality decision. Hence, there is a consensus that timeliness is an essential qualitative characteristic of quality financial reports (Belkaoui, 2002). It remains a noteworthy mechanism in reducing rumours, leaks and insider trading in emerging capital markets (Owosu-Ansah, 2000).

Business operations are fast becoming more complex. So also, is the growth of the investment community on the rise, and investors are making great demand for more timely and relevant information. The concept of timeliness in financial reports has been widely dealt with by accounting bodies, regulatory bodies, authorities and organizations globally. For example, the New York Stock Exchange (NYSE), the U.S Security and Exchange Commission (SEC), and the Nigerian Security and Exchange Commission (SEC), have all laid down certain requirements regarding the timing of published financial reports (Abdelsalam \& Street, 2007).

Corporate governance and financial reporting are highly interwoven. In fact, financial reporting forms a crucial part of the corporate governance mechanism (Melis, 2004; Melis \& Carta, 2010). Similarly, the responsibility for appropriate and timely financial reporting rests on the shoulder of the apex governing body of a firm "the board of directors". Furthermore, the foremost aim of financial reporting activity is to make available high-quality information; while corporate governance as part of it objective, provides a platform to ensure the quality of financial reports published. In recent times, corporate governance has come to be a matter of great concern in the corporate world because of the increasing high-profile scandals and crash of some companies like Lehman Brothers, WorldCom Enron in the United States, Parmalat in Italy, Marconi in Britain, Nortel in Canada, One Tel in Australia, the Volkswagen Emissions Scandal, the FIFA Corruption Scandal, Toshiba Accounting Scandal and so many other recent accounting based scandals (Uwuigbe et al., 2017). These happenings in the global financial world dealt a big blow to investor confidence and assurance on the quality of financial information provided by management. The failures of these large organizations have led to the implementation of measures to the improvement of corporate governance mechanisms and a more intense interest in financial reports by stakeholders.

In Nigeria, the banking sector is highly regulated because of the past incidence of poor corporate governance, poor risk management policies, inadequate internal control systems and poor quality of financial reporting, hence, making it susceptible to scandals and failure. In order to address this problem, this led to the implementation of corporate governance regulations as an antidote. According to Arabsalehi and Ziaee (2010), the code of corporate governance in Nigeria in 2003, is regarded as the standard in the corporate society in Nigeria. The link between corporate governance and quality of financial reports has been intensely discussed in developed context, with scarce evidence from emerging economies (Klai \& Omri, 2011) consequently, there is no conclusive evidence of the influence of corporate governance on the quality of financial reports as proxy by timelines of financial reporting for emerging economies. Furthermore, a study into the timeliness of financial reports would be of great importance on the way to improving investors' confidence and decreasing the tailbacks related with financial reporting in Nigeria. Hence, this study aims to examine the influence of corporate governance mechanisms on the quality of financial reports in Nigeria. It will attempt to determine the extent, to which board size affects the quality of financial reports. More so, it will examine the association between board independence and reliability of financial statements. Finally, it will examine the relationship between the foreign board executives and quality of financial reports. The residual part of this paper consists of the following sections; literature review and hypotheses development, methodology, discussions and findings, conclusion and recommendation. 


\section{LITERATURE REVIEW AND HYPOTHESES DEVELOPMENT}

\subsection{Theoretical framework}

This study adopts the agency theory as a framework for this research because it gives insight into the agent behavior and the agent-principal relationship. Management (agent) in playing their role of disclosing financial information to the shareholders (owners) and other stakeholders may give misleading information mainly due to their selfish gains. The issue of corporate governance arose from the activities of managers or agents in sharp practices, which usually are not in the principals (owners of the business) interest. Over time, situations have risen where the directors do not take action in shareholders' best interest. This problem forms the core issue which agency theory addresses. This problem arises because of the disassociation of the control of a firm from ownership of such firm, hence the directors control the firm while the shareholders are the owners. This arrangement invariably gives birth to a conflict of interest amongst ownership (shareholders) and control (directors). This conflict of interest is the foremost problem that the principle of corporate governance intends to address. Companies should, therefore, seek to limit this principal-agent problem through a solid and effective corporate governance policy. Corporate governance through the corporate governance mechanisms can be used to check and monitor the activities and operations of the agent, thereby ensuring that they are in line with the principals' interests. This enables the owners to overcome the issues of lack of credible information. This study focused on corporate governance mechanisms like board size, ownership structure, board independence, Foreign Expatriates on the Board, and their various effects on the timeliness of financial reports.

\subsection{Concept of corporate governance}

Corporate governance remains a key concept that has enjoyed a great deal of public interest, this is due to the economic and financial implication it has for the well-being of companies and the so- ciety in general (Solabomi \& Uwuigbe, 2013; Uwuigbe, Daramola, \& Anjolaoluwa, 2014). The World Bank report (2002) described the concept of corporate governance as "the set of rules that influence expectations about the use of control over resources of a firm". Sloan (2002) opined that the first source of true and independent financial information about a firm's performance is through its financial reports; this importance makes financial reporting a focal point of attraction to managers as well as the rest key stakeholders. Basically, corporate governance ensures that shareholders, managers and other key stakeholders in an organization discharge their responsibilities within the framework of transparency, accountability, and ethics. According to Kachouri, Ben Saad, and Jarboui (2015), the board of directors is the key control mechanism of any organization. Prior studies (Singh, Mathur, \& Gleason, 2004; Yermack, 1996) have come to the conclusion that the structure of the board of directors have an influence on the timely financial reports.

\subsection{Board size and quality of financial reports}

Patrick, Paulinus, and Mympha (2015) emphasized that corporate governance mechanisms like the firm size and board size have a strong impact on the timeliness of financial reports. From the perspective of agency theory, it can be argued that agency problems are easier tackled by larger boards because of the presence of greater number of people evaluating and observing management decisions (Bugshan, 2005). Monks and Minnow (1995) in a related study proved that larger boards have the capability to commit more time and effort in managing the company's activities, while smaller boards commit less effort and time in overseeing the activities of the management. Klein (2002) shared a similar view on this topic by proposing that board monitoring is done more effectively by larger boards due to the inherent ability to share the responsibility amidst a larger sum of people. $\mathrm{Yu}$ (2008) acknowledged that larger boards have a strong relationship with lesser levels of earnings management. Yermack (1996) and Byard, Li, and Weintrop (2006) argued large boards confirm the value relevance of financial reports. Ezat and ElMasry (2008) opined that the variability of the board's membership together with their desire to 
reveal more timely financial information will attract the interest of more investors. This suggests that the larger the board, the greater the desire for more timely disclosures. In contrast to these findings, Jensen (1993), Yermack (1996) and Eisenberg, Sundgren, and Wells (1998) all found out that an "overcrowded" or "large" boards are most likely to be ineffective in carrying out its oversight fiction over a firm. What is "overcrowded" is, however, relative. According to Jensen (1993), smaller boards are most likely to give room for efficient and effective communication and coordination between the board and the management. Similarly, Vafeas (2000), Bradbury, Mak, and Tan (2006), and Ahmed, Hosain, and Adams (2006) were all of the opinion that large boards deplete the information content and increases the earnings management. Nevertheless, other did not confirm this link (Firth, Fung, \& Rui, 2007). Therefore, based on the gap in the literature, this study predicts that:

H01: Board size does not significantly affect the quality of financial reports.

\subsection{Board independence and quality of financial reports}

In corporate governance literature, independent directors are usually proxies for board independence. An independent director is one that is free from the control of the Chief Executive Officer (Peasnell, Pope, \& Young, 2000). Peasnell et al. (2000) and Klein (2002) observed that earnings management is usually mitigated by an independent board, which in the long run improves the timeliness of financial reports. In Britain, Beeks, Pope, and Young (2004) found out that board independence allows dissemination of timely financial information by UK firms. Similarly, Canavan, Jones, and Potter (2004) opined that an independent board advances the quality of financial reports of Chinese firms; Peasnell et al. (2000) and Davidson, Godwin, and Kent, (2005) have confirmed a strong link between of board independence and the quality of financial reports. Firth et al. (2007) opined that an independent board advances the quality the financial reports. Dimitropoulous and Asteriou (2010) and Marra, Marzzola, and Prencipe (2011) asserted that the independence of the board has a significant positive relationship with the timeliness of financial reporting. Kantudu and Samaila (2015) affirmed that a more independent board produces more timely financial information. Joseph and Ahmed (2017), in their work on the effects of corporate governance on the timeliness of financial reports in Nigeria, affirmed that board independence has a significant positive effect on the timeliness of financial reports.

However other studies provided a contrasting opinion on the aforementioned argument. Jaggi, Leung, and Gul (2007) observed that a strong negative relationship exists between the timeliness of financial information and a higher fraction of independent directors. Oba (2014) opined that board independence has a significantly negative effect on the quality of financial reports, which in other words means that the existence of more independent directors does not guarantee the timeliness of financial reports. Gulzar and Wang (2011), however, did not find any sort of pragmatic proof on the relationship between quality of financial reports and board independence. Other studies such as Ahmed, Hossain, and Adams (2006), Bradbury, Mak, and Tan (2006), and Petra (2007) have argued that independent directors do not have enough power to control managers and as such do not have any influence on the timeliness of financial reports. Furthermore, Petra (2007) observed that independent directors are sufficient mechanisms to control and influence managers, but their incidence on the board may have no impact on the quality of information. The finding of Ho and Wong (2001) support Petra's (2007) observations. Thus, based on the inconclusive results, this study postulates that:

H02: Board independence does not significantly affect the quality of financial reports.

\subsection{Foreign directors and quality of financial reports}

The appointment of foreign directors is currently a trend in most companies across the corporate world (Maryam, Michael, Steve, \& Shane, 2016). This group of directors are unique because of their connections with another country, which may give room for adding new knowledge and expertise to the board. Nevertheless, they could be quite expensive because of the cost attributed to presence of the 
travelling expenses, distance and their non-familiarity with the nation of the firm where they are directors (Miletkov, 2013). Although the importance of their presence on the board clearly understood, the expertise of the foreign directors on the board is usually the best in monitoring the timeliness of financial reports. Furthermore, Park and Shim (2003) observed a positive sort of link between the presence of foreign expatriates on the board and the timeliness of financial reports. In contrast, Abdul and Mohamhed (2006) in their research revealed a negative relationship between the presence of foreign expatriates on the board and the quality of financial reports. Bedrad, Chotorou, and Courteau (2003) in their study of British firms opined that foreign expatriate on the board (FEB) has no sort of relationship with the quality of financial reports; Dimitropoulos and Asteriou (2010) established this claim.

H03: Foreign executives on board do not significantly affect the quality of financial reports.

\section{MATERIAL AND METHODS}

In order to successfully analyze the link between corporate governance and quality of financial information on Nigerian banks, the study adopted the panel data regression analysis technique. Panel data, according to Pesaran, Shin, and Smith (2000), is the "repeated observation on the same cross-section, typically of individual variables that are observed for several time periods". Hence, this study adopts this method due to the fact that the data gathered were both time-series and cross-sectional data. Judgmental sampling technique was adopted in the selection of the sample. It also adopts the use of secondary data for the period 2008 to 2015 for 15 sampled banks listed on the Nigerian Stock Exchange (NSE). The sampled listed banks were used as a measure of the effects of corporate governance mechanisms on the quality of financial information, because their financial information was relatively more easily assessable available.

\subsection{Accounting quality (TIME)}

Different authors have been defined Accounting quality differently; nevertheless, in this research work, it has been defined in terms of 'timeliness'. According to Uwuigbe et al. (2016), timeli- ness of financial information has been described as a qualitative trait of financial reports; this is because it has the capacity to materially affect the decisions of the users. According to McGee (1998), timeliness of financial reporting is the time it takes to disclose the financial information to the members of the public. Consequently, it is measured by the natural logarithm of a number of days between year-end and the signature of the auditors' report after year-end. In the context of this research, this study used quality of financial reporting, timeliness and accounting quality interchangeably. Hence, the longer the time, the less the accounting quality and vice versa.

\subsection{Model specification}

Various corporate governance variables have been used in previous studies (Klein, 2002; Kajola, 2008; Love, 2011). These variables are Board Size (BSIZE), Board Chair/Chief Executive Status (CEOSTATUS) and Audit Committee (AUDCOM). However, this study adopted a relatively new proxy for measuring corporate governance which was excluded in previous studies. This is Foreign expatriate on the board (FEB). In order to determine the effect of corporate governance on the quality of financial report in the banking sector, a linear regression model equation was used. The two constructs involved in this study are corporate governance and quality of the financial report. The regression equation can be expressed as:

$$
Y=\beta_{0}+\beta x_{i t}+\mu_{i t} .
$$

Equation (1) can be defined as:

$$
I S=f(C G)+c \mu .
$$

"Demonstrating equation two (2) with the variables of the model, therefore, the equation below is formed with the presence of a control variable (size of the firm)". Therefore, the equation becomes

\section{$F R Q=f($ Board size $;$ Director Independence}

Ownership structure;

foreign expatriates on board).

The above can be deducted to the model below with the inclusion of a control variable, which is the size of the firm. 
$F R Q=B D S_{1-t}+B I N D_{1-t}+$

$+F E B_{1-t}+$ Board Size.

Therefore, the regression equation is:

$$
\begin{aligned}
& F R Q=\beta_{0}+\beta_{1} B D S_{1-t}+ \\
& +\beta_{2} B I N D_{1-t}+\beta_{3} F E B_{1-t}+\mu,
\end{aligned}
$$

where $F R Q$ - quality of financial report, $B D S$ board size. This captures the numbers of board members in the bank. BIND - director independence. This is obtained from the ratio of total number of independent. directors on the Committee divided by the total number of directors. FEB - foreign expatriates on the board. This captures the proportion of total foreign expatriates on the board divided by board size. Control variable (which captures the natural $\log$ of total asset). $\beta$ - coefficient of parameter, it - time coefficient, this is the time frame being considered in the study, $\mu$ - error term.

\section{DISCUSSION OF FINDINGS}

Table 1 shows the result of descriptive figures for all variables used in the study. Findings from the descriptive summary as depicted in Table 1 present a mean of 1.65 , a maximum and minimum values of 1.98 and 1.20 , respectively, for the quality of financial report (FRQ). This suggests that averagely, banks listed on the floor of the NSE publish their financial statements late. Also, the mean value for board size (BDS) as depicted in Table 1 was 15. This invariably suggests that on the average, boards for most of the quoted banks in Nigeria are made up of 15 members. In addition, results from the descriptive statistics present a mean distribution of $54 \%$, with maximum and minimum values of 0.81 and 0.30 for board independence (BIND). This indicates that the board independence status for the selected banks stood at $54 \%$, which implies that, there is a higher fraction of independent directors than executive directors on the board. Foreign expatriates on the board (FEB) maintained a mean stat of 0.93 with maximum and minimum stat of 5 and 0 , respectively. The outcome invariably implies that the mean value of foreign expatriates on the board is very low suggesting the absence of foreign executives on the boards of most Nigerian banks. From the analysis, it can be seen that the standard deviation values are close to zero meaning the mean values are reliable and there is very little volatility in the sample

Table 1. Descriptive statistics of variables

\begin{tabular}{|c|c|c|c|c|}
\hline Variable & FRQ & BDS & BIND & FEB \\
\hline Mean & 1.649917 & 15.00000 & 0.543417 & 0.925000 \\
\hline Median & 1.605000 & 15.00000 & 0.500000 & 0.500000 \\
\hline Maximum & 1.980000 & 29.00000 & 0.810000 & 5.000000 \\
\hline Minimum & 1.200000 & 10.00000 & 0.300000 & 0.000000 \\
\hline Std. dev. & 0.175181 & 2.637799 & 0.100716 & 1.244568 \\
\hline Skewness & 0.036165 & 1.500705 & 0.193278 & 1.508111 \\
\hline Kurtosis & 2.189565 & 9.680739 & 2.988530 & 4.726197 \\
\hline Jarque-Bera & 3.310187 & 268.2037 & 0.747783 & 60.38678 \\
\hline Probability & 0.191074 & 0.000000 & 0.688051 & 0.000000 \\
\hline Sum & 197.9900 & 1800.000 & 65.21000 & 111.0000 \\
\hline Sum Sq. Dev. & 3.651899 & 828.0000 & 1.207099 & 184.3250 \\
\hline Observations & 120 & 120 & 120 & 120 \\
\hline
\end{tabular}

Source: Authors' computation (2017) using Eview 8.0.

Table 2. Correlation matrix

Source: Authors' computation (2017) using Eview 8.0.

\begin{tabular}{l|c:c:c:c}
\hline Variable & FRQ & BDS & BIND & FEB \\
\hline FRQ & 1.000000 & 0.035280 & 0.058552 & 0.251659 \\
BDS & 0.035280 & 1.000000 & 0.055987 & 0.074232 \\
& 0.058552 & 0.055987 & 1.000000 & -0.053582 \\
FEB & 0.251659 & 0.074232 & -0.053582 & 1.000000 \\
\hline
\end{tabular}

Table 2 presents the correlation matrix of the independent and dependent variables for the study. It basically reflects the relative strength of the linear relationship between the explanatory variables. According to Gujarati (2004), multicollinearity could only be a problem if the pair-wise correlation coefficient among regressors is above 0.80 . However, results from the correlation matrix table show that foreign expatriate on board (FEB) is strong and positively correlated with quality of financial reports (FRQ). On the other hand, the outcome for board independence (BIND) and board size (BDS) show a positive correlation with quality of financial reports (FRQ). Therefore, based on this outcome, the problem of multicollinearity is absent among the independent variables. 
Table 3. Hausman test

Source: Authors' computation (2017) using Eview 8.0.

Correlated Random Effects - Hausman Test

Test cross-section random effects"**

\begin{tabular}{c|c|c|c}
\hline Test summary & $\begin{array}{c}\text { Chi-sq. } \\
\text { statistic }\end{array}$ & $\begin{array}{c}\text { Chi-sq. } \\
\text { d.f. }\end{array}$ & Prob. \\
\hline Cross-section random & 2.557057 & 3 & 0.4651 \\
\hline
\end{tabular}

Note: ${ }^{* *}$ mean significant at $5 \%$.

\section{Interpretation}

The Hausman test was carried out to determine which model is appropriate for the panel regression. The Hausman test rule is as follows:

If the $P$-value is statistically significant, accept the alternative hypothesis (Fixed Effect Model).

If the $P$-value is not statistically significant, accept the null hypothesis (Random Effect Model).

However, analysis of the findings shows that the $P$-value $(0.4651)>5 \%$ significance level, so the null hypothesis is accepted and the alternative hypothesis is accepted, which interprets that a random effect model should be used for the regression analysis.

\section{DISCUSSION OF PANEL REGRESSION RESULTS}

Deciding between the random effects (RE) model or fixed effects (FE) model as the suitable model for the study hinges on whether the individual effect was random or fixed. After comparing the fixed-effects with random-effects results using the Hausman test, the findings, as depicted in Table 3, show random-effects estimates of $p<0.05$. Hence, the null hypothesis is accepted. While the fixedeffects model is rejected. More so, since the p-value of Chi-square (0.4651) as shown in Table 3 is greater than 0.05 , findings from this study will be discussed with respect to the random effects output shown in Table 3. Therefore, based on the random-effects regression estimate results are depicted in Table 3 . With respect to the $R$-squared, the independent variables jointly explained 29 percent of the variations in the dependent variable. Consequently, the adjusted R-squared shows that the independent variables have a $23 \%$ explaining power of the dependent variable. Similarly, results from the Fisher's ratio displayed in Table 4 shows a p-value less than 0.05 (i.e. $0.000016<0.05$ ); this result suggests that the association between the explanatory variables and the dependent variable is linear. Also, it suggests that the independent variables together are significantly related with the dependent variable. The Durbin-Watson is 1.100122, which falls within the acceptable region and shows the presence of low auto-serial correlation which is common in time series data. This confirms the statistical reliability of the model. Therefore, the model shows that there exists a significant link between corporate governance and quality of financial reporting in Nigeria.

Findings for the first hypothesis which states that board size does not significantly affect the quality of financial reports as depicted in Table 4 show a

Table 4. Regression result for panel data

Source: Authors' computation (2017).

\begin{tabular}{|c|c|c|c|c|}
\hline Variable & Coefficient & Std. error & t-statistic & Prob. \\
\hline FEB & 0.029520 & 0.011455 & 2.577143 & 0.0113 \\
\hline BIND & 0.041029 & 0.142064 & 0.288808 & 0.7733 \\
\hline BDS & -0.003325 & 0.005562 & -0.597833 & 0.5512 \\
\hline C & 1.650190 & 0.112255 & 14.70032 & 0.0000 \\
\hline \multicolumn{5}{|c|}{ Effects specification (Period fixed (dummy variables) } \\
\hline R-squared & 0.299323 & \multicolumn{2}{|c|}{ Mean dependent variable } & 1.649917 \\
\hline Adjusted R-squared & 0.235040 & \multicolumn{2}{|c|}{ S.D. dependent variable } & 0.175181 \\
\hline S.E. of regression & 0.153216 & \multicolumn{2}{|c|}{ Akaike info criterion } & -0.826742 \\
\hline Sum of squared residuals & 2.558803 & \multicolumn{2}{|c|}{ Schwarz criterion } & -0.571222 \\
\hline Log likelihood & 60.60451 & \multicolumn{2}{|c|}{ Hannan-Quinn criterion } & -0.722974 \\
\hline F-statistic & 4.656377 & \multicolumn{2}{|c|}{ Durbin-Watson statistic } & 1.100122 \\
\hline Prob (F-statistic) & 0.000016 & \multicolumn{2}{|c|}{-} & - \\
\hline
\end{tabular}


non-significant but negative association between board size and the quality of financial reports of the appraised banks. This outcome is evident in the $\mathrm{t}$-values and $\mathrm{p}$-values $(C$-coef $=-0.003325$; $p=0.5512>0.05)$, respectively. This result suggests that a unit upsurge in the board size will invariably lead to a -0.003325 unit of reduction in the quality of financial reports of the sampled banks. This means that an upsurge in the board size gives room for ineffectiveness of the oversight function of the board in ensuring the timeliness and quality of financial reporting. This outcome corroborates the findings of Bradbury, Mak, and Tan (2006), Abdul-Raman and Muhammed-Ali (2006) and Ahmed, Hosain, and Adams (2006), where a similar result was observed. However, it contradicts the findings of $\mathrm{Yu}$ (2008) and Byard, $\mathrm{Li}$, and Weintrop (2006) who found a positive relationship.

Also, results for the second hypothesis (which states that board independence does not significantly affect the quality of financial reports) as depicted in Table 4 show that board independence has a non-significant positive influence on the quality of financial reports of banks in Nigeria. This is evident in the $t$-values and $p$-values $(C$-coef $=0.041029 ; p=0.7733>0.05)$. Hence, the null hypothesis which states that board independence does not significantly affect the quality of financial reports is accepted. This outcome implies that a unit increase in board independence induces a 0.041029 unit improvement in the quality of financial reports of the sampled banks. This could mean that the more independent the board is, the more likely it is to improve and encourage timely and quality financial reporting. This could be cen- tred on the fact that an independent director is one that is free from the control of the Chief Executive Officer (CEO). This outcome is in line with the findings by Petra (2007), Gulzar and Wang (2011), however, they contradict the findings of Kantudu and Samaila (2015) and Joseph and Ahmed (2017).

Similarly, findings on the third hypothesis (Foreign executives on board do not significantly affect the quality of financial reports) as depicted in Table 4 show a significant positive link between foreign executives on board and the quality of financial reports published by the appraised banks in Nigeria. This is depicted in the $\mathrm{t}$-values and $p$-values $\quad(C$-coef $=0.029520 ; \quad p=0.0113<0.05)$. Hence, the null hypothesis is rejected. This outcome basically suggests that the incidence of foreign executives on the board significantly impacts the timeliness of financial statements. This result implies that an additional foreign executive added to the board will induce a 0.029520 increase in the quality of financial reports. This outcome is in consonance with the findings of Park and Shim (2015), however, the outcome contradicts the findings of Bedrad, Chotorou, and Courteau (2003) and Abdul and Mohamhed (2006).

Table 5. Analysis of null hypotheses

\begin{tabular}{|c|c|c|}
\hline Null hypotheses & Accept & Reject \\
\hline $\begin{array}{l}\text { H01: Board size does not } \\
\text { significantly affect the quality of } \\
\text { financial reports }\end{array}$ & $v$ & - \\
\hline $\begin{array}{l}\text { H02: Board independence does } \\
\text { not significantly affect the quality } \\
\text { of financial reports }\end{array}$ & $v$ & - \\
\hline $\begin{array}{l}\text { H03: Foreign executives on } \\
\text { board do not significantly affect } \\
\text { the quality of financial reports }\end{array}$ & - & $v$ \\
\hline
\end{tabular}

\section{CONCLUSION AND RECOMMENDATIONS}

This paper examined the influence of corporate governance on the quality of financial reports in Nigeria. The governance mechanisms used in this study include board size, board independence and the presence of foreign executives on the board. From the analysis above, it was observed that corporate governance apparently has a significant influence on the timeliness of financial reports. The study concludes that larger boards become more incompetent, because they tend to aggravate poor decision making and slow down the decision-making process. Furthermore, the study concludes that the inclusion of non-executive directors tend to offer an unbiased contribution to the board as they are perceived as reliable mechanisms to moderate agency conflicts between shareholders and managers. Finally, the study concludes that the presence of foreign executives on the board will improve the quality of financial statements of listed banks in Nigeria as they tend to provide their expertise and diversity in experience to the 
board. This, in turn, will improve the financial reporting process and ultimately improving the timeliness of financial reports among listed banks in Nigeria. The study, however, recommends that the number of directors on the board should be of a reasonable size. Also, in order to guarantee timely financial reports, large and overcrowded boards should be discouraged in Nigerian listed banks. This will foster faster communication, coordination and ultimately timely publishing of financial reports. In addition, the study recommends that the presence of foreign executives on the board should be encouraged as they tend to provide more financial expertise knowledge to the board on financial reporting issues.

\section{LIMITATION AND SUGGESTION FOR FUTURE STUDY}

This study is limited to only three corporate governance variables which are board size, board independence, and FEB. However, other variables like Directors tenure can be taken into consideration in future research. Also, further research can be done on other fractions of the Nigerian economy such as the manufacturing sector.

\section{ACKNOWLEDGEMENT}

We acknowledge Covenant University for the platform and financial support provided toward the completion and publication of this research work.

\section{REFERENCES}

1. Abdesalam, O., \& El-Masry, A. (2008). The impact of board independence and ownership structure on the timeliness of corporate internet reporting of Irish listed companies. Journal of Managerial Finance, 34(12), 907-918. Retrieved from https:// www.dur.ac.uk/research/directory/ staff/? mode=staff\&id $=12774$

2. Abdesalam, O. H., \& Street, D. L. (2007). Corporate governance and the timeliness of corporate internet reporting by UK listed companies. Journal of International Accounting, Auditing, and Taxation, 16(2), 111130. Retrieved from https://pdfs. semanticscholar.org/f8cd/17ed25f77 ca4752cfdb11611eb7d9309421e.pdf

3. Abdul, R., \& Mohamhed, A. (2006). Board, audit committee, culture and earnings management: Managerial Auditing Journal, 22(7), 783-804. Retrieved from https://www.emeraldinsight.com/doi/full/10.1108/026 86900610680549 ? $\mathrm{src}=$ recsys

4. Adeyemi, S. B., \& Fagbemi, T. O. (2010). Audit quality, corporate governance and firm characteristics in Nigeria. International Journal of
Business and Management, 5(5), 169-179. Retrieved from www. ccsenet.org

5. Ahmed, K., Hossain, M., \& Adams, B. (2006). The effects of board composition and board size on the informativeness of annual accounting earnings. An International Review, 14(5), 418431. https://doi.org/10.1111/j.14678683.2006.00515.x

6. Alexander, D., \& Britton, A. (2000). Financial reporting (5th ed.). London: International Business Press. Retrieved from https://www. abebooks.co.uk/book-search/title/ financial-reporting/author/alexander/

7. Arabsalehi, M., \& Ziaee, M. (2010). The relationship between corporate governance mechanism and earnings quality of listed companies in the Tehran stock exchange. Financial Accounting, 2(5), 39-56 Retrieved from https:// pdfs.semanticscholar.org/5938/3f6 18abe24f5d89797242f1dcc6d1eab 9e7e.pdf

8. Ballesta, J., \& Meca, E., (2009). Corporate governance and earnings management: A metaanalytics. An International Review, 17(5), 594-610. https:// doi.org/10.1111/j.14678683.2009.00753.x

9. Bedrad, J., Chotorou, S., \& Courteau, L. (2004). The effect of audit committee expertise, independence, and activity of aggressive earnings management. AUDITING: a Journal of Practice and Theory, 23(2), 13-35. https:// doi.org/10.2308/aud.2004.23.2.13

10. Beeks, W., Pope, P., \& Young, S. (2004). The link between earnings timeliness, earnings conservatism, and board composition: Evidence from the UK, corporate governance. An International Review, 12(1), 47-59.

11. Belkaoui, A. (2002). Accounting theory (4th ed). London: Thomson Learning. Retrieved from https:// trove.nla.gov.au/work/6450110

12. Bradbury, M., Mak, Y., \& Tan, S. (2006). Board characteristics, audit committee characteristics, and abnormal accruals. Pacific Accounting Review, 18(2), 47-68. Retrieved from www.ftms.edu.my/ 
journals/brPaper.php?codec $=$ dow nloadCount\&paperid $=249$

13. Brown, P., Dobbie, G. W., \& Jackson A. B. (2011). Measures of the timeliness of earnings. Australian Journal of Management, 21, 222-234. Retrieved from https://ssrn.com/abstract $=1490162$

14. Bugshan, T. (2005). Corporate governance, earnings management and the information content of accounting earnings: Theoretical Model and Empirical Tests (Ph.D. Dissertation). Bond University, Australia. Retrieved from https:// epublications.bond.edu.au/theses/ bugshan/

15. Byard, D., Li, Y., \& Weintrop, J. (2006). Corporate governance and the quality of financial analyst's information. Journal of Accounting and Public policy, 609-625. https:// doi.org/10.1016/j.jaccpubpol.2006.07.003

16. Canavan, J., Jones, B., \& Potter, M. J. (2004). Board tenure: How long is too long? Boards and Directors, 28, 39-42. Retrieved from https:// www.directorsandboards.com/ articles/singleboard-tenure-howlong-too-long

17. Dalton, D., Daily, R., Ellstrand, C., \& Johnson, M. (1998). Meta-analytic reviews of board composition, leadership structure \& financial performance. Strategic Management Journal, 19, 269280. Retrieved from https://pdfs. semanticscholar.org/b266/6bae3 4b392064d1952c17fa2b3b64f4f3 dc0.pdf

18. Davidson, R., Godwin S. J., \& Kent, P. (2005). Internal governance structures and earnings management. Journal of Accounting and Finance, $45,241-467$. Retrieved from https://onlinelibrary.wiley. com/doi/abs/10.1111/j.1467 629x.2004.00132.x

19. Dimitropoulos, P. E., \& Asteriou, D. (2010). The effect of board composition on the informativeness and quality of annual earnings: Empirical evidence from Greece. Research in International Business and Finance,
24(2), 773-784. Retrieved from https:/ideas.repec.org/a/eee/riibaf/ v24y2010i2p190-205.html

20. Eisenberg, T., Sundgren, S., \& Martin T. W. (1998). Larger board size and decreasing firm value in small firms. Journal of Financial Economics, 48, 35-54. Retrieved from https://scholarship.law.cornell.edu/facpub/393/

21. Emeni, F. K., Uwuigbe, O. R., Uwuigbe, U., \& Erin, O. A. (2016). International financial reporting standards and stock market behavior: The Nigerian experience. Review of Economic Studies and Research Virgil Madgearu, 9(2), 49-66. Retrieved from https://www. econjournals.com/index.php/ijefi/ article/download/4053/pd

22. Ezat, \& El-Masry, (2008). The influence of corporate governance and firm characteristics on the timeliness of corporate internet reporting by companies in Malaysia. Journal of Economics and Finance, 35, 156-16. Retrieved from https://www.sciencedirect.com/science/article/pii/.../ pdf?md5 ...pid=1-s2.0...1

23. Fama, E., \& Jensen, M. C. (1983). Separation of ownership and control. Journal of Law and Economics, 26, 301-305. Retrieved from https://pdfs.semanticscholar.org/94a8/f1e59b6424fd96ad7e28588efa04fccf042b.pdf

24. Firth, M., Fung, P., \& Rui, O. (2007). Ownership, two-tier board structure and the informativeness of earnings: Evidence from China. Journal of Accounting and Public Policy, 26(4), 17-34. https://doi.org/10.1016/j.jaccpubpol.2007.05.004

25. Ho, S. S. M., \& Wong, K. S. (2001). The study of the relationship between corporate governance structure and the extent of voluntary disclosure. Journal of International Accounting, Auditing, and Taxation, 10(2), 139-156. https://doi.org/10.1016/S10619518(01)00041-6

26. Jaggi, B., Leung, S., \& Gul, F. A. (2007). Board independence and earnings management in Hong Kong firms: Some evidence on the role of family ownership and family board control (Working paper). Department of Accounting and Information System, Rutgers University.

27. Joseph, B. A., \& Ahmed, A. B. (2017). Corporate governance and financial reporting quality in Nigeria. International Journal of Information Research and Review, 4(2), 3749-3753. Retrieved from http://www.ijirr.com/corporategovernance-and-financial-reporting-quality-nigeria

28. Kachouri, M., BenS'aad, \& Jarboui, A. (2015). Accounting conservatism and earning timeliness: Impact on corporate governance index. International Journal of Advanced Research, 10, 132-14.

29. Kajola, S. (2008). Corporate governance and firm performance: The case of Nigerian listed firms. European Journal of Economics, Finance and Administrative Sciences, 1, 16-28.

30. Kantudu, A. L., \& Samaila, I. A. (2015). Board characteristics, independent audit committee and financial reporting quality of oil marketing firms: Evidence from Nigeria. Journal of Finance, Accounting, and Management, 6(2), 34-50. Retrieved from https://www.questia.com/library/ journal/1P3-3690967901/boardcharacteristics-independent-auditcommittee

31. Karamonou, I., \& Vefas, N. (2005). The Association between boards and audit committees with management earnings forecast: An empirical analysis. Journal of Accounting Research, 43(3), 453-486. https://doi.org/10.1111/ j.1475-679X.2005.00177.x

32. Klai, N., \& Omri, A. (2011) Corporate Governance and Financial Reporting Quality: The Case of Tunisian Firms. International Business Research, 4(1), 158-66. http://dx.doi. org/10.5539/ibr.v4n1p158

33. Klein, A. (2002). Audit committee, board of director characteristics and earnings management. Journal of Accounting and Economics, 33, 375-400. Retrieved 
from https://papers.ssrn.com/sol3/ papers.cfm?abstract_id=316695

34. Leventis, S., Weetman, P., \& Caramis, C. (2005). Financial reporting in emerging capital markets: determinants of audit report lag: Some evidence from the Athens stock exchange. International Journal of Auditing, 9, 45-48. https://doi.org/10.1111/j.10991123.2005.00101.x

35. Lewis, R., \& Pemdrill, D. (1996). Advanced financial accounting $\left(7^{\text {th }}\right.$ ed). London: Pearson Education. Retrieved from https://www. amazon.com/Advanced-FinancialAccounting...Lewis/dp/0273658492

36. Lipton, M., \& Lorsch, J. W. (1992). A modest proposal for improved corporate governance. Business Law Review, 48(1), 59-77. Retrieved from www.sciepub.com/reference/63403

37. Love, I. (2011). Corporate governance and firm performance around the world: What we know and what we don't know. The World Bank Research Observer, 26(1), 4270. Retrieved from https://elibrary. worldbank.org/doi/abs/10.1093/ wbro/lkp030

38. Mainoma, M. (2002). An assessment of the quality of financial reporting in Nigeria. Journal of Business Administration, 2(1), 116-127.

39. Marra, A., Mazzola, P., \& Prencipe, A. (2011). Board monitoring and earnings management Pre and Post IFRS. International Journal of Accounting, 49(2), 205-230. https:// doi.org/10.1016/j.intacc.2011.04.007

40. McGee, R., \& Yuan, X. (2011). Corporate governance and the timeliness of financial reporting: A comparative study of the People's Republic of China, The USA, and the European Union. Journal of Asia Business Studies, 6(1). https://doi. org/10.1108/15587891211190679

41. Melis, A., \& Carta, S. (2010). Does accounting regulation enhance corporate governance? Evidence from the disclosure of share based remuneration. Journal of Management and Governance, 14(4), 435-446. Retrieved from https://ssrn.com/abstract $=1373938$
42. Miletkov, K. (2013). Investor protection and the role of firm level financial transparency in attracting foreign investment. The Financial Review, 50(3), 393-434. https://doi.org/10.1111/fire.12072

43. Monks, R., \& Minow, N. (2001). A managerial emphasis ( $2^{\text {nd }} \mathrm{ed}$.). Oxford: Blackwell publishers. Retrieved from https://www.amazon.com/Corporate-GovernanceRobert-G-Monks/dp/0470972599

44. Morck, R., Schleifer, A., \& Vishny, R. (1989). Alternative mechanism for corporate control. American Economic Review, 79, 41-56. Retrieved from https://econpapers.repec.org/RePEc:aea:aecrev:v :79:y:1989:i:4:p:842-52

45. Nassar, L. M., Uwuigbe, O. R., Uwuigbe, U., \& Abuwa, J. T. (2014). IFRS Adoption and its integration into accounting education curriculum in Nigerian universities. Research Journal of Finance and Accounting, 5(22), 76-82. Retrieved from http:// eprints.covenantuniversity.edu. ng/id/eprint/4282

46. Oba, V. C. (2014). Board dynamics and financial reporting quality in Nigeria. Review of International Corporative Management, 15(2), 226-236. Retrieved from https://ideas. repec.org/a/rom/rmcimn/v15y2014i2p226-236.html

47. Okereke, O. (2009). Corporate governance and global competitiveness in financial market institutions. Journal of Securities and Finance, 7(2), 7-16.

48. Owusu-Ansah (2000). Timeliness of corporate financial reporting in emerging capital markets: Empirical evidence from the Zimbabwe Stock Exchange. Accounting and Business Research, 30(3), 241-254. Retrieved from https://www.tandfonline.com/ doi/abs/10.1080/00014788.2000. 9728939

49. Park, Y., \& Shim, H. (2015). Board composition and earnings management in Canada. Journal of Corporate Finance, 10(3), 416431. Retrieved from https://econpapers.repec.org/RePEc:eee:corfin :v:10:y:2004:i:3:p:431-457
50. Patrick, Paulinus, \& Nympha, (2015). The influence of corporate governance on earnings management practices: A study of some selected quoted companies in Nigeria. American Journal of Economics, Finance and Management, 1(5), 482-493. Retrieved from https://scholar. google.com/citations? user=13W9 7pAAAAAJ\&hl=en

51. Peasnell, K. V., Pope, P. F., \& Young, S. (2000). Accrual management to meet earnings targets: UK evidence Pre- and Post-Cadbury. British Accounting Review, 32(4), 415-445. Retrieved from https://www.sciencedirect.com/science/article/pii/ S0890838900901343

52. Pesaran, M., Shin, Y., \& Smith, R. (2000). Structural analysis of vector error correlation models with exogenous variables. Journal of Econometrics, 97(2), 293-343. Retrieved from www.sciepub.com/ reference $/ 214720$

53. Petra, S. (2007). The effects of corporate governance on the informativeness of earnings. Journal of Economics and Governance, 8, 129-152. Retrieved from https://link.springer.com/article/10.1007/s10101-006-0018-8

54. Singh, M., Mathur, I., \& Gleason, K. (2004). Governance and performance implications of diversification strategies: Evidence from large US firms. The Financial Review, 39(4), 489-526. https://doi.org/10.1111/j.07328516.2004.00086.x

55. Sloan, R. (2002). Financial accounting and corporate governance. Journal of Accounting and Economics, 16, 335-347. Retrieved from https://econpapers.repec.org/ RePEc:eee:jaecon:v:32:y:2001:i:13:p:335-347

56. Solabomi, O. A., \& Uwuigbe, U. (2013). Effects of corporate governance on corporate social and environmental disclosure among listed firms in Nigeria. European Journal of Business and Social Sciences, 2(5), 76-92. Retrieved from www.iiste.org/ Journals/index.php/RJFA/article/ viewFile/31812/32684 
57. Uwuigbe, O. R., Uwalomwa, U., Jimoh, J., Ebeguki, E. I., \& Olufemi, A. O. (2016). Value relevance of financial statements and share price: A study of listed banks in Nigeria. Banks and Bank Systems, 11(4-1), 135-143. http:// dx.doi.org/10.21511/bbs.11(41).2016.04

58. Uwuigbe, U., Agba, L. U., Jimoh, J., Olubukunola, R. U., \& Rehimetu, J. (2017). IFRS adoption and earnings predictability: evidence from listed banks in Nigeria. Banks and Bank Systems, 12(1), 166-174. http://dx.doi. org/10.21511/bbs.12(1-1).2017.10

59. Uwuigbe, U., Francis K. E., Uwuigbe, O.R., \& Ataiwrehe, C. M. (2016). International financial reporting standards adoption and Accounting Quality: Evidence from the Nigerian Banking Sector. Corporate Ownership \& Control, 14(1-1), 287-294. http://doi. org/10.22495/cocv14ilclp12

60. Vaefas, N. (2000). Board structure and informativeness of earnings. Journal of Accounting and Policy, 19(2), 139-160. Retrieved from https://pdfs.semanticscholar.org/ f473/16c28458e088ae91c6dcc3e5a ecf7f6306c7.pdf

61. Vaefas, N. (2005). Board meeting frequency and firm performance. Journal of Financial Economics, 53, 113-132.

62. Yermack, D. (1996). Higher market valuation of companies with a small board of directors.
Journal of Financial Economics, 40, 185-211. Retrieved from https://www.sciencedirect.com/science/article/ pii/0304405X95008445

63. Yu, F. (2008). Corporate governance and earnings management. Journal of Financial Economics, 88, 245-271. Retrieved from https://econpapers.repec.org/RePEc:eee:jinec:v :88:y:2008:i:2:p:245-271

64. Zaitul, Z. A. (2010). Board of directors, audit committee, auditor characteristics, and timeliness of financial reporting in listed companies in Indonesia (Thesis). University of Utara, Malaysia. Retrieved from http:// etd.uum.edu.my/id/eprint/2405 